\title{
Soil seed bank, fire season, and temporal patterns of germination in a seeder-dominated Mediterranean shrubland
}

\author{
Blanca Céspedes • Iván Torres • Belén Luna • \\ Beatriz Pérez $\cdot$ José M. Moreno
}

Received: 1 August 2011/Accepted: 26 September 2011

(C) Springer Science+Business Media B.V. 2011

\begin{abstract}
Soil seed banks play a major role in the post-fire regeneration of Mediterranean shrublands. They vary throughout the year in species composition, abundance, and readiness to germinate. After fire, germination occurs mainly during the following fall to spring. Time of germination can determine recruitment success. It is unclear what factors control postfire germination and its timing. We tested the effects of season and fire on the readily germinable soil seed bank of a seeder-dominated shrubland. Plots were burned early and late in the summer season (ES, LS). Soil samples were collected before and after fire, and germinated in a chamber simulating successively autumn, winter, and spring conditions. Samples were kept moistened at all times. Fire intensity was similar between ES and LS. Several species of Cistus and herbs, mostly annuals, were dominant. Most germination occurred during the simulated-autumn period, with little subsequent germination during the following two periods. Germination speed $\left(T_{50}\right)$ during simulated-autumn was similar for shrubs and herbs, and independent of season or fire. Germination was lower for two shrubs (Rosmarinus officinalis, Cistus salvifolius) and higher for herbaceous dicots in LS than in ES soils. Fire reduced monocots and enhanced
\end{abstract}

B. Céspedes · I. Torres · B. Luna · B. Pérez ·

J. M. Moreno ( $\square)$

Department of Environmental Sciences, University

of Castilla-La Mancha, 45071 Toledo, Spain

e-mail: josem.moreno@uclm.es
Cistus. Germination period significantly interacted with fire and season in some groups or species, altering the simulated-autumn germination peak. We demonstrate that the seed bank can germinate swiftly under simulated-autumn conditions. Hence, water availability is the main controlling factor of germination. Fire season differentially affected some species or groups, and could affect the post-fire regeneration.

Keywords Cistus - Germination temperature · Global change $\cdot$ Rainfall patterns $\cdot$ Regeneration strategy $\cdot$ Rosmarinus

\section{Introduction}

Fire-prone shrublands cover large areas in the Mediterranean region, and many are dominated by seeders, that is, species that re-establish from seeds stored in the soil (Trabaud 1994). In the western part of the Mediterranean region, rainfall occurs from fall to spring. Germination of shrubs after fire usually proceeds after the onset of the first significant rainfall. However, not all seeds germinate at the same time. Often, germination occurs from early fall to the end of spring of the first post-fire year. In addition, some germination can occur during the second and third year (Quintana et al. 2004; De Luis et al. 2008). While rainfall patterns are assumed to cause these variations (Daskalakou and Thanos 2004; Quintana et al. 2004), seed dormancy can also play a role in controlling time 
of germination (Ooi 2010). Time of germination can be critical since early germination during the first year can increase survival success, while second or third year germinated seedlings have a much reduced chance of surviving (Quintana et al. 2004; De Luis et al. 2008). Therefore, knowledge of the temporal patterns of germination of shrubs once soils have appropriate moisture levels, and the factors that control them is needed to understand plant demographic changes in relation to fire.

Herbs, particularly annuals, are a common component of Mediterranean shrublands. After fire, they regenerate from seeds stored in the soil (Ortega et al. 1997; Valbuena and Trabaud 2001), forming a dense, species-rich layer of vegetation in the first few years after fire (Arianoutsou-Faraggitaki 1984; Pérez and Moreno 1998; Keeley et al. 2006). Although the temporal post-fire germination pattern of herbaceous species in shrublands is poorly understood, studies in grasslands indicate that germination proceeds as soon as soils have appropriate moisture, following the first autumn rains (Espigares and Peco 1993; Traba et al. 2006). Since herbs may interact with shrub establishment and growth (Moreno and Oechel 1992; Keeley et al. 2006; Seifan et al. 2010), an understanding of the factors that control their abundance and their temporal germination after fire can be equally important for determining the fate and composition of the post-fire plant community (Figueroa et al. 2004).

In the Mediterranean region, fires commonly occur during summer, but can span several months within a year, from spring to fall (Vázquez and Moreno 1998). The time of fire within the year, or fire season, can be important (Enright and Lamont 1989; Knox and Clarke 2006), since it can interact with the post-fire regeneration from the soil seed bank in various ways. Fuel characteristics and soil moisture content vary during the year, and could affect fire severity and impact seed mortality or release from dormancy (Auld and Bradstock 1996). In addition, the amount of seeds in the soil will vary depending on the time of fire. Seed dispersal is highest during the summer for both shrubs and herbs (Espigares and Peco 1993; Bastida and Talavera 2002; Traba et al. 2006). However, among shrubs, there is great disparity in temporal patterns of dispersal. Some species (e.g., Cistus ladanifer) disperse from summer to spring of the next year; others (e.g., Rosmarinus officinalis) start dispersing in spring and proceed until early summer (Moreno and Cruz
2000; Bastida and Talavera 2002; Clemente et al. 2007). Data on temporal patterns of seed dispersal of herbaceous species in shrublands are sparse (Buisson et al. 2006), but studies in Mediterranean grasslands indicate that dispersal occurs mainly in summer, with little variability among species (Espigares and Peco 1993; Ortega et al. 1997).

In addition, the degree to which seeds will be exposed to heat in case of fire is also likely to change during the season. Recently dispersed seeds may be more vulnerable to the lethal effects of heat than older seeds, some of which may have escaped predators by occupying protected sites that may be less exposed to fire (Auld and Bradstock 1996; Traba et al. 2006). Therefore, the current seed rain might not be so important in determining the post-fire germination (Clemente et al. 1996; Bastida and Talavera 2002; Traba et al. 2006).

After fire, and once seeds are exposed to the appropriate moisture and temperature conditions, temporal germination patterns may differ among species due to their different sensitivity to environmental cues for germinating (Reyes and Trabaud 2009). Furthermore, even within a species, not all seeds may germinate simultaneously due, among other factors, to variation in dormancy status. For instance, in species with enforced dormancy, older seeds are more likely to have their dormancy broken than younger seeds (Baskin and Baskin 1998). In addition, seed sensitivity to dormancy-breaking cues also varies seasonally (Ooi 2010). Hence, fires occurring early in the season may affect a different proportion of nondormant seeds than late season fires. As a result, the temporal pattern of germination may vary depending on when a fire occurs.

The objectives of this study were to determine the effect of season and fire on total germination and temporal patterns of emergence of the soil seed bank of a seeder-dominated Mediterranean shrubland. To investigate this, soils were collected from plots before and after burning in early and late summer, and were germinated in a chamber in which the course of autumn, winter, and spring conditions was consecutively simulated. The questions addressed were to what extent the readily germinable soil seed bank varies between early and late summer? How does fire affect this? Assuming that rainfall starts in fall and proceeds until spring, in which period of time (autumn, winter, or spring) will germination occur? 
Does germination period vary between soils collected in early and late summer or with fire?

\section{Materials and methods}

Study area

The study site was located at Los Puntales, in the Sierra Morena mountain range, southwestern Spain $\left(4^{\circ} 43^{\prime} \mathrm{W}, 38^{\circ} 03^{\prime} \mathrm{N} ; 550 \mathrm{~m}\right.$ elevation) (Fig. 1a). The climate is Mediterranean, with mean annual temperature of $17.3^{\circ} \mathrm{C}$, and mean annual rainfall of $633 \mathrm{~mm}$ (Guadalmellato Reservoir meteorological station,

\section{(a)}

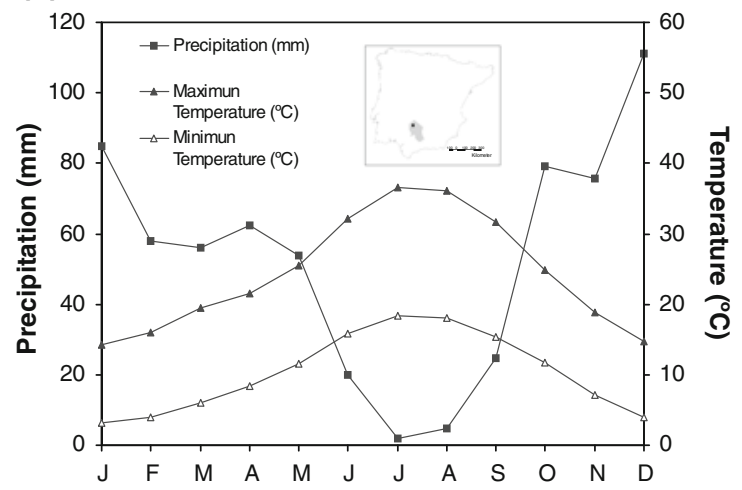

(b)

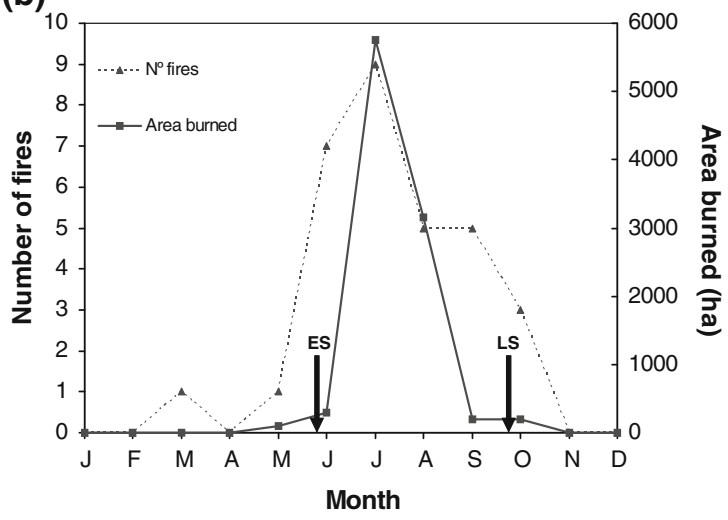

Fig. 1 a Monthly mean rainfall and temperature trends from 1970 to 2003 measured at the Guadalmellato Reservoir meteorological station (Córdoba), $4^{\circ} 40^{\prime} \mathrm{W}, 38^{\circ} 02^{\prime} \mathrm{N}, 217 \mathrm{~m}$ elevation. Location of the study site (Los Puntales, Córdoba province, Spain) is shown in the embedded figure. b Number of fires and total area burned during 1974-2008 within the $10 \times 10 \mathrm{~km}$ UTM grid cell where the study area is located. Arrows indicate the time of experimental fires in early (ES) and late (LS) summer located at $5 \mathrm{~km}$ from the site). Mean minimum temperatures occur in January, and freezing conditions are common during winter. Mean maximum temperatures occur in July (Fig. 1a). The dry season lasts from May to September, and mean rainfall in this period is $50 \mathrm{~mm}$. The bedrock is granitic and the soils are regosols (FAO 1974). Fires in the region occur mainly between June and September (Fig. 1b).

The study area was covered by a 12-year-old shrubland. Pre-fire plant abundance was estimated in 20, $1 \mathrm{~m} \times 1 \mathrm{~m}$ squares, regularly distributed along two, $20 \mathrm{~m}$ transects within each of eight plots (see below). The $1.5-2.5 \mathrm{~m}$ high, dense $(75 \%$ cover $)$ vegetation was dominated by obligate seeders, including Cistus ladanifer L. (23\% cover), C. albidus L., C. populifolius L. and C. salvifolius L. (approx. 5\% cover each), and Rosmarinus officinalis L. (7\% cover). Other abundant facultative seeders (i.e., resprout but also regenerate from seeds) were Adenocarpus telonensis (Loisel.) DC. (17\%), and Teucrium fruticans L. (5\%). Herbaceous cover was $14 \%$.

\section{Experimental design}

Four blocks were established, running parallel to a north-facing slope. The area was fenced to exclude large herbivores. Within each block, two $25 \mathrm{~m} \times 25 \mathrm{~m}$ plots were established following a completely randomized blocks design to assign treatments. Burning treatments were conducted in early summer (end of June, referred to as "early season" or ES) and in late summer (end of September, "late season" or LS), coinciding with the beginning and end of the fire season. All plots were burned on the same day at each time (ES, LS) by igniting them at the bottom and letting the fire propagate upslope and downwind. Surface temperatures were monitored with 20 k-thermocouples (HOBO Type K Thermocouple; Onset Computer Corporation, Bourne, MA, USA) distributed throughout each plot. From these measurements, we calculated two indices of fire intensity: mean maximum soil surface temperature during fire, and time of residence of temperatures equal or greater than $100^{\circ} \mathrm{C}\left(T_{r \geq 100^{\circ} \mathrm{C}}\right)$.

Seed bank sampling and germination

Soil samples were collected shortly before fire (unburned soils) and immediately after it (burned 
soils), at five different locations within each plot. Each sample consisted of 15 cylindrical cores (diameter of $6 \mathrm{~cm}$; depth of $4 \mathrm{~cm}$ ). Samples were taken to the laboratory, air dried, and passed through a sieve $(2 \mathrm{~mm}$ mesh). From each sample, $100 \mathrm{~g}$ of soil was evenly spread onto plastic trays $(18 \mathrm{~cm} \times 27 \mathrm{~cm} \times 4.5 \mathrm{~cm})$ that contained a $2 \mathrm{~cm}$ layer of sterilized sand. We used the seedling emergence method to estimate the size of the soil seed bank (Fenner and Thompson 2005). The layer of soil in the trays did not exceed $1 \mathrm{~cm}$ depth. Eighty-four trays were used, with 40 trays per season (ES and LS), 20 of which were burned (+), and 20 unburned (-) soil samples. Four trays, filled with sterilized sand, were used to detect any seed contamination, although none was detected.

The experiment lasted 21 weeks, comprising three simulated seasonal periods, each corresponding to three different germination conditions that mimicked light/dark photoperiod and temperature in autumn $\left(12 \mathrm{~h} / 12 \mathrm{~h}, 17.5^{\circ} \mathrm{C} / 10^{\circ} \mathrm{C}\right)$, winter $\left(10 \mathrm{~h} / 14 \mathrm{~h}, 12.5^{\circ} \mathrm{C} /\right.$ $\left.5^{\circ} \mathrm{C}\right)$, and spring $\left(12 \mathrm{~h} / 12 \mathrm{~h}, 20^{\circ} \mathrm{C} / 12.5^{\circ} \mathrm{C}\right)$. These temperature patterns were based on records from the Guadalmellato Reservoir meteorological station. Each period lasted 6 weeks, plus 1 week of transition from one period to the next. All trays were positioned randomly in a walk-in growth chamber. Trays were irrigated every 2 days to keep them permanently moist. Emerging seedlings were monitored weekly and identified to the species level. When the identification was not possible, seedlings were transplanted to pots and grown until this was possible. A number of Poaceae species could not be identified; therefore, they were combined into a single group as monocotyledons. Germination (seedling density; No $\mathrm{m}^{-2}$ ) was recorded by periods (simulated-autumn, simulated-winter, and simulated-spring) and analyzed for all species together or the various groups (woody or herbs), and, within these, by the main species of woody seeders, or by monocots and dicots within the herbs (monocots and dicots from now on), respectively. Species richness was analyzed only for the dicots.

Germination rates, that is, the time (weeks) required for $50 \%$ of all germinations $\left(T_{50}\right)$ during the first period (simulated-autumn), were calculated for various species or group of species. Germination during the other two periods was very low (see "Results" section), and further testing within them became meaningless. Plant nomenclature followed Flora Europaea (Tutin et al. 1964-1980).
Statistical analysis

Differences between fires in early (ES) and late (LS) summer for mean maximum surface temperatures and $T_{r \geq 100^{\circ} \mathrm{C}}$ were analyzed by one-way ANOVA. Species richness and seedling density of all species combined, or of the various groups or main woody species were tested for the effects of season (S) [two levels, early season (ES), and late season (LS)], fire (F) [two levels, unburned $(-)$ or burned $(+)$ ], and germination period (P) [three levels, simulated-autumn, simulated-winter, and simulated-spring]. This was done by employing a repeated measures, three-factor ANOVA, using general linear models (GLM) in which season and fire were between-subjects factors and germination period the within-subject factor (repeated measures). Differences in $T_{50}$ (weeks) were analyzed by two-way (fire, season) ANOVA. Prior to all statistical analyses, the data were tested for normality and homoscedasticity, and transformed as appropriate. Species richness and seedling densities were square root-transformed and $T_{50}$ was log-transformed. All statistical analyses were completed using the SPSS Statistic 17.0 package for Windows (SPSS, Chicago, IL, USA).

\section{Results}

The mean $( \pm \mathrm{SE})$ maximum surface temperature during fire was $550 \pm 28^{\circ} \mathrm{C}$ for ES fires and $699 \pm 45^{\circ} \mathrm{C}$ for LS fires. Mean $( \pm \mathrm{SE}) T_{r \geq 100^{\circ} \mathrm{C}}$ was $5.8 \pm 0.8 \mathrm{~min}$ for ES burns and $8.3 \pm 1.1 \mathrm{~min}$ for LS burns (Fig. 2). The values of both parameters were higher, although more variable, for the LS than ES fires. There were, however, no significant statistical differences between fires $\left(F_{1,6}=4.7, P=0.073\right.$ and $F_{1,6}=0.27, P=0.62$, for maximum temperatures and $T_{r \geq 100^{\circ} \mathrm{C}}$, respectively). Therefore, we accepted the null hypothesis that ES and LS fires were of similar fire intensity.

Forty-two species were identified in unburned soils, 34 in ES- and 35 in LS - (Table 1). The number of species in burned soils was 32 in ES+ and 34 in LS+. The majority of the species were herbs, which were common to the two treatments (season, fire); only three annuals appeared exclusively in ES soils and four in LS ones. Of all dicot species present in the prefire aboveground vegetation, $62 \%$ of them germinated from the soil seed bank, including all woody obligate seeders. 

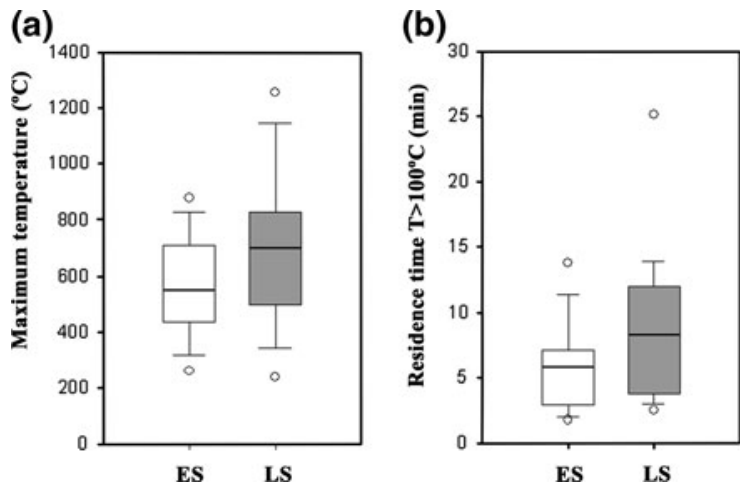

Fig. 2 Box plots of: a maximum soil surface temperatures reached during fire; $\mathbf{b}$ time of residence $(\mathrm{min})$ at or above $100^{\circ} \mathrm{C}$ during the experimental fires carried out in early (ES) and late (LS) summer in a seeder-dominated Mediterranean shrubland at Los Puntales. The boxes show the mean (solid line), quartiles, 5 and $95 \%$ ranges (error bars) and extreme values (outliers-open circles)

Total seedling density was higher in LS than in ES soils, and lower in burned (+) than in unburned (-) soils (Table 1); however, differences due to season or fire were non-significant (Table 2). Woody species accounted for $11 \%$ of the seedling population; Cistus was the most abundant group, representing nearly $90 \%$ of the woody seedlings in all treatments, except in ES-, where $R$. officinalis was dominant, albeit very variable among treatments (Table 1 ). Herbs dominated the soil seed bank (89\% of all seedlings), and were more abundant than woody seedlings under all treatment combinations. Among the herbs, about 33\% of them were monocots (Poaceae), and the rest dicots; these had higher densities in all treatments (Table 1).

Germination began shortly after watering the soils, and progressed swiftly. By the end of the simulatedautumn period, $86 \%$ of the woody seedlings and $89 \%$ of the herbaceous seedlings had emerged (Fig. 3a, b). Germination during the simulated-winter period was very low (11 and 9\% for woody plants and herbs, respectively), and even lower under the simulatedspring period ( 3 and $2 \%$ for woody plants and herbs, respectively) (Table 1). Almost all species recorded in the experiment had germinated before the end of the simulated-autumn period. Only two species appeared during the simulated-winter period and exclusively in burned soils. No new species were recorded during the simulated-spring period (Fig. 3c).

Herb seedling density was significantly affected by season of collection (Table 2), being greater in LS than in ES soils, owing mainly to the dicots (Fig. 4a). However, season neither significantly affected species richness (dicots, woody), nor woody species density, but did have a significant effect on the density of some species. This altered the relative dominance of the various species in the population of seedlings (Fig. 4b). For example, R. officinalis and C. salvifolius produced a significantly greater number of seedlings in ES than in LS soils. In contrast, the other woody species had greater absolute germination in LS than in ES, although the effect of season on these species was not statistically significant (Table 2; Fig. 4b).

Burned soils yielded a lower number of seedlings than unburned soils, particularly of herbs (Table 1), but differences among them were not always significant. Monocot seedling density was significantly lower in burned than in unburned soils in both seasons (Tables 1, 2). By contrary, differences were not statistically significant for woody species, despite having a larger number of seedlings in burned than in unburned soils. This resulted from the different species-specific response to fire. Germination of Cistus species was promoted by fire, most notably in the case of $C$. ladanifer and C. albidus, although only the last one showed statistically significant differences. There was no significant season-fire interaction for either woody or herbaceous species (Table 2).

The time to reach $50 \%$ of total germination $\left(T_{50}\right)$ during simulated-autumn was generally between 2 and 3 weeks (Table 3 ). Woody species had higher $T_{50}$ values than herbs (i.e., they germinated at a slower pace). However, there were no significant effects $(P>0.05)$ due to season, fire or their interactions for any of the groups analyzed.

Germination period (simulated-autumn, simulatedwinter, or simulated-spring) was a significant factor on seedling density for most of the groups and species analyzed, including species richness (Table 2). This reflects that most germination occurred under the simulated-autumn period. Furthermore, germination period significantly interacted with season, resulting in a smaller simulated-autumn germination peak in LS than in ES soils in the case of $R$. officinalis and in the opposite effect in the dicots. In addition, germination period significantly interacted with fire for all herbaceous species and each of the two herbaceous groups (dicots and monocots) - there was a smaller simulated-autumn germination peak in burned than unburned soils. Interactions were also found between 


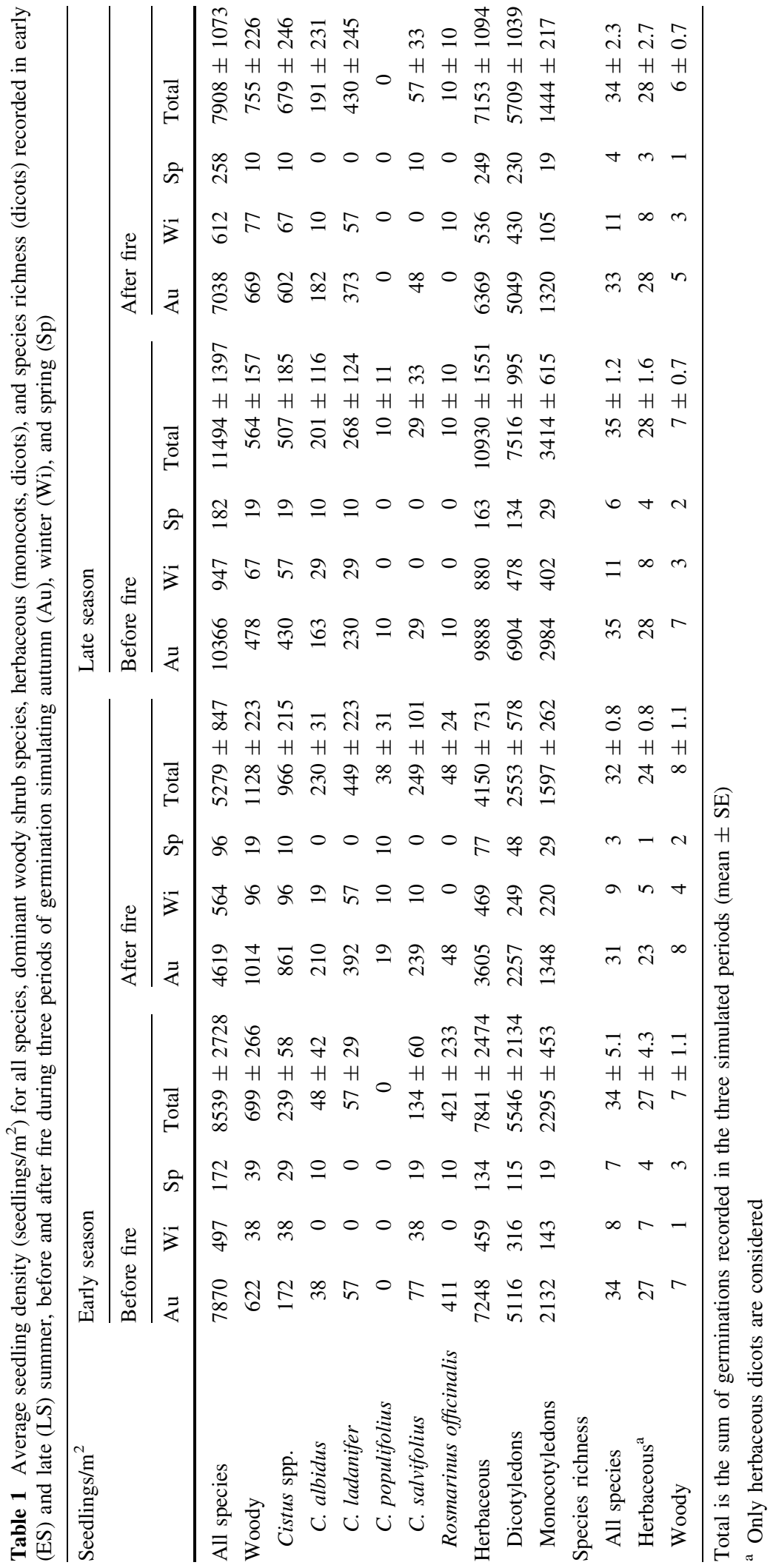


Table $2 P$ values from three-way, repeated measures ANOVA for seedling density (seedlings $/ \mathrm{m}^{2}$ ) for all species, dominant woody shrub species, herbaceous (dicots, monocots), and species richness (dicots)

\begin{tabular}{|c|c|c|c|c|c|c|c|}
\hline \multicolumn{8}{|l|}{ Factor effects } \\
\hline & $S$ & $\mathrm{~F}$ & $\mathrm{~S} \times \mathrm{F}$ & $\mathrm{P}$ & $\mathrm{P} \times \mathrm{S}$ & $\mathrm{P} \times \mathrm{F}$ & $\mathrm{P} \times \mathrm{S} \times \mathrm{F}$ \\
\hline \multicolumn{8}{|l|}{ Seedlings $/ \mathrm{m}^{2}$} \\
\hline All species & 0.071 & 0.120 & 0.914 & $<0.001$ & 0.146 & 0.041 & 0.631 \\
\hline Woody & 0.394 & 0.196 & 0.556 & $<0.001$ & 0.377 & 0.136 & 0.752 \\
\hline Cistus spp. & 0.941 & 0.034 & 0.162 & $<0.001$ & 0.889 & $<0.001$ & 0.066 \\
\hline C. albidus & 0.256 & 0.049 & 0.061 & $<0.001$ & 0.690 & 0.018 & 0.416 \\
\hline C. ladanifer & 0.387 & 0.112 & 0.435 & $<0.001$ & 0.679 & 0.067 & 0.658 \\
\hline C. populifolius & 0.337 & 0.337 & 0.121 & 0.157 & 1.000 & 1.000 & 0.157 \\
\hline C. salvifolius & 0.036 & 0.393 & 0.887 & 0.001 & 0.140 & 0.129 & 0.276 \\
\hline Rosmarinus officinalis & 0.026 & 0.110 & 0.110 & 0.003 & 0.005 & 0.061 & 0.173 \\
\hline Herbaceous & 0.048 & 0.080 & 0.971 & $<0.001$ & 0.071 & 0.009 & 0.621 \\
\hline Dicotyledons & 0.045 & 0.194 & 0.591 & $<0.001$ & 0.032 & 0.019 & 0.773 \\
\hline Monocotyledons & 0.335 & 0.011 & 0.068 & $<0.001$ & 0.590 & 0.010 & 0.459 \\
\hline \multicolumn{8}{|l|}{ Species richness } \\
\hline All species & 0.135 & 0.463 & 0.976 & $<0.001$ & 0.364 & 0.190 & 0.152 \\
\hline Herbaceous $^{\mathrm{a}}$ & 0.073 & 0.306 & 0.662 & $<0.001$ & 0.329 & 0.663 & 0.320 \\
\hline Woody & 0.559 & 0.409 & 0.417 & $<0.001$ & 0.163 & 0.092 & 0.206 \\
\hline
\end{tabular}

Statistically significant $P$ values are shown in bold

$S$ season, $F$ fire, $P$ period of germination

${ }^{a}$ Only herbaceous dicots are considered

germination period and fire for Cistus, particularly for C. albidus (Table 2). In this case, however, the effect was the opposite, and the simulated-autumn germination peak was greater in burned than unburned soils.

\section{Discussion}

Prompt germination after soil watering under simulated-autumn was the norm for shrubs and herbs. Three weeks after watering the soils, half of the total germination had already occurred, and 6 weeks later germination was nearly complete. Few seedlings continued to germinate under simulated-winter or simulated-spring. Mean $T_{50}$ during simulated-autumn was 2-3 weeks, which is consistent with laboratory experiments (Reyes and Trabaud 2009; Moreira et al. 2010). Swift germination during simulated-autumn was particularly evident in species richness. Since our experiment simulated only one wet season cycle, we cannot exclude that further germination could occur if additional cycles had been simulated. Nevertheless, experiments in another shrubland in which soils were monitored for germination for 15 months, after allowing them to undergo a drying cycle, indicated that germination in the second cycle was minimal (Torres et al. 2012).

Fire did not affect the germination speed $\left(T_{50}\right)$ of woody or herbaceous species during simulated-autumn. In woody species with physical dormancy (Cistus), this appears to contradict findings that germination speed varies depending on exposure of seeds to heat or other fire-cues (Reyes and Trabaud 2009). Indeed, the number of Cistus germinating was greater in burned than in unburned soils. That is, in burned soils a portion of the germinated seeds must have been initially dormant (Troumbis and Trabaud 1987; Roy and Sonie 1992; Clemente et al.1996). How many seeds germinating in burned soils belonged to the non-dormant or dormant but fire-stimulated fractions is unknown. Anyhow, either both types of seeds germinated at the same speed or if they differed in this characteristic, its number was not sufficient to produce significant differences in the germination speed of the soil seed bank.

Simulated-autumn was the period in which most germination occurred. There were, however, minor 


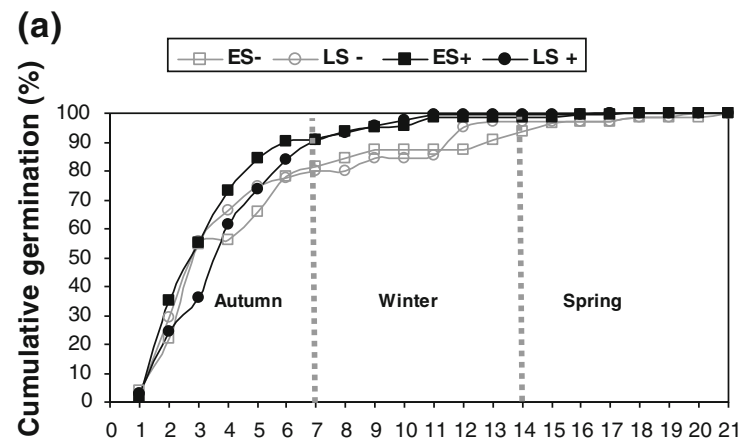

(b)
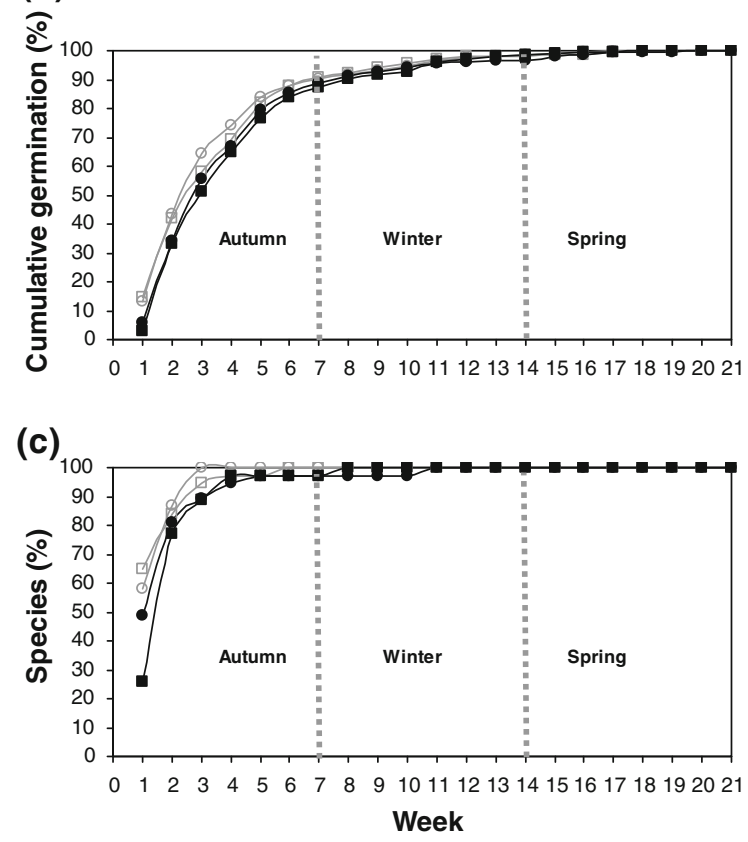

Fig. 3 Cumulative germination (\%) through time under three periods of germination simulating autumn, winter, and spring, for soils collected in early (ES) and late (LS) summer, before (-) and after (+) fire, for a woody species; b herbaceous species; and $\mathbf{c}$ species richness

changes to this pattern depending on the species, fire, and season. In Cistus and herbs, fire interacted with period of germination. Whereas in Cistus, fire tended to further increase germination in simulated-autumn, in the case of herbs it relatively reduced this peak. In absolute terms, however, the vast majority of germinations still occurred during simulated-autumn, which indicates that the impact of these changes, if they materialize in the field, are probably not important. A relative anticipation (Cistus) or delay (herbs) could be relevant if it affected the herbs-shrubs interactions
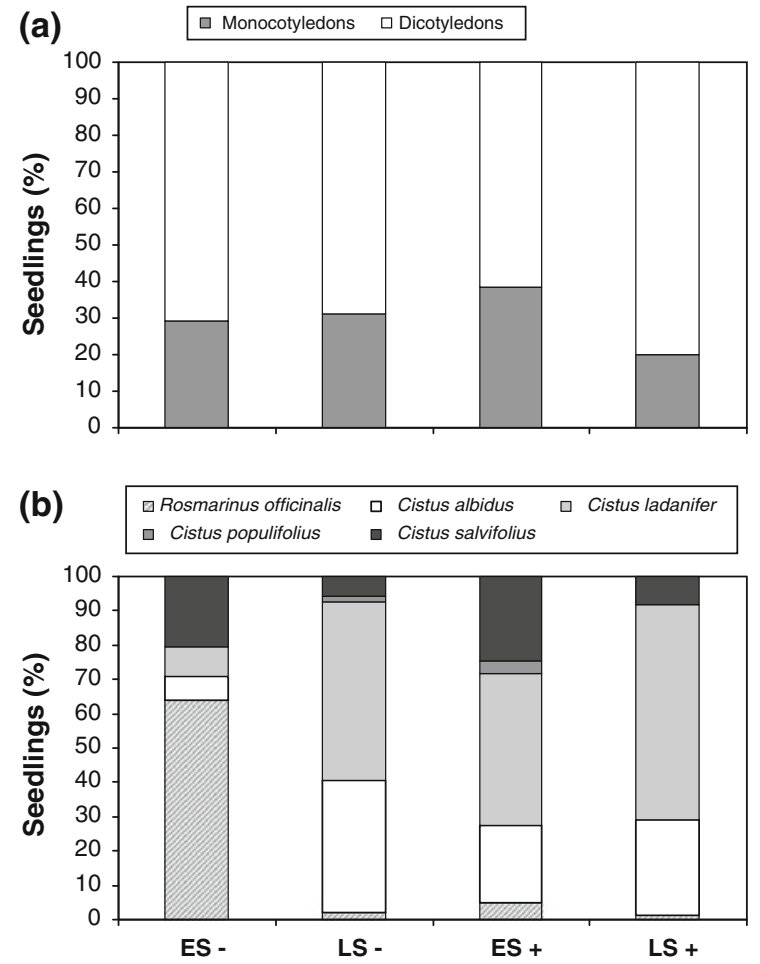

Fig. 4 Relative contribution (\%) of the various plant groups to the total number of seedlings germinated for a herbaceous species (monocots, dicots); b dominant woody shrubs (Cistus spp. and $R$. officinalis), in early (ES) and late (LS) summer, before $(-)$ and after $(+)$ fire

(Moreno and Oechel 1992; Seifan et al. 2010), but this remains to be tested.

Season did not significantly affect germination speed $\left(T_{50}\right)$; hence, seeds in ES soils germinated at a speed similar to those in LS soils. Assuming that the soil seed bank in LS soils was enriched with seeds dispersed during summer, it appears that they germinated at about the same speed as the older seeds of ES soils. Season significantly interacted with germination period for the dicots. In this case, the germination of this group during simulated-autumn was more pronounced in LS than in ES soils. No increased germination in simulated-winter or simulated-spring in LS soils in comparison with ES was observed, as would have been expected if cold requirements or other mechanisms of physiological dormancy had been present (Baskin and Baskin 1998). These data corroborate laboratory experiments that showed that cold exposure is not required for germination in several groups of Mediterranean species (GiménezBenavides et al. 2005; Luna et al. 2008), although this 
Table 3 Average $( \pm \mathrm{SE})$ time (weeks) to reach $50 \%$ of the total germination $\left(T_{50}\right)$ during the simulated-autumn period from soils collected in early (ES) and late (LS) summer, before and after fire, and for various groups of species

\begin{tabular}{|c|c|c|c|c|c|c|c|}
\hline \multicolumn{5}{|l|}{$T_{50}$ (week) } & \multicolumn{3}{|c|}{ Factor effects } \\
\hline & \multicolumn{2}{|l|}{ Early season } & \multicolumn{2}{|l|}{ Late season } & \multirow[t]{2}{*}{ Season } & \multirow[t]{2}{*}{ Fire } & \multirow[t]{2}{*}{ Season $\times$ fire } \\
\hline & Before fire & After fire & Before fire & After fire & & & \\
\hline All species & $2.44 \pm 0.44$ & $2.64 \pm 0.43$ & $2.08 \pm 0.28$ & $2.53 \pm 0.25$ & 0.515 & 0.280 & 0.664 \\
\hline Woody & $3.08 \pm 0.74$ & $2.55 \pm 0.34$ & $2.42 \pm 0.32$ & $3.29 \pm 0.32$ & 0.836 & 0.565 & 0.096 \\
\hline Cistus spp. & $3.79 \pm 0.90$ & $2.55 \pm 0.39$ & $2.54 \pm 0.36$ & $3.25 \pm 0.38$ & 0.716 & 0.722 & 0.070 \\
\hline Herbaceous & $2.38 \pm 0.42$ & $2.41 \pm 0.49$ & $2.06 \pm 0.27$ & $2.44 \pm 0.23$ & 0.198 & 0.209 & 0.886 \\
\hline Dicotyledons & $2.49 \pm 0.31$ & $2.85 \pm 0.45$ & $2.10 \pm 0.28$ & $2.45 \pm 0.18$ & 0.758 & 0.516 & 0.544 \\
\hline Monocotyledons & $1.62 \pm 0.29$ & $2.32 \pm 0.46$ & $2.56 \pm 0.42$ & $2.43 \pm 0.44$ & 0.128 & 0.376 & 0.213 \\
\hline
\end{tabular}

$P$ values of the two-way ANOVA (fire, season) are shown

may not apply to all shrubby species (Trigueros Vera et al. 2010). As discussed above, the impact of these changes in the relative temporal patterns of germination on the shrub-herbs interactions is probably not very important since the simulated-autumn germination peak was dominant, although field studies need to verify this.

In unpredictable environments, species may increase their fitness by, among other, extending the time period during which germination occurs (Fenner and Thompson 2005). On the other hand, rapid germination has been suggested to be advantageous for plant fitness (Verdú and Traveset 2005). In this study, germination under both, simulated-winter or simulated-spring periods, was very low, since most seeds germinated under simulated-autumn. Thus, early germination was clearly favored.

Season and fire affected the germination of shrubs in different ways. For example, season significantly affected $R$. officinalis and $C$. salvifolius but not the other shrubs, by increasing germination in ES soils. This pattern could be supported by seed dispersal patterns in R. officinalis not in C. salvifolius. Indeed by the end of spring, $R$. officinalis has released most of its seeds (Moreno and Cruz 2000), which are nondormant. Moreover, R. officinalis soil seed bank demonstrates substantial year to year fluctuations, is usually smaller than co-occurring Cistus, and the viability of its seeds is low (Salvador and Lloret 1995). Its seed bank, therefore, can be considered transitory (Clemente et al. 2007). Not being a fire-dependent species (Trabaud and Casal 1989; Salvador and Lloret 1995; Reyes and Trabaud 2009; but see Moreira et al. 2010), it seems a good candidate to be affected by fire season, whereby fire in late season would be more detrimental than in early season, as found here. The pattern found for $C$. salvifolius is difficult to explain since its phenology is similar to other Cistus species (Trabaud and Oustric 1989; Salvador and Lloret 1995), and points to the need to better understanding the interactions between phenology, seed production, and seed persistence in the soil seed bank for some dominant species in Mediterranean shrublands.

The lack of a significant season effect on the other shrub species is intriguing since a large number of seeds are produced every year, part of which must be incorporated into the soil bank (Bastida and Talavera 2002). On average, there were twice as many Cistus seedlings in the unburned plots in LS than in ES soils, a likely indication of the incorporation of new seeds to the soil bank. It is arguable that seed predation must be very high during summer, so that the abundance in the soil seed bank is lower than what would be expected based on seed production. Therefore, the long period of seed dispersal of Cistus might be advantageous to reduce the risk of seed predation, by releasing seeds throughout most of the year, including winter and spring, when the activity of ants is minimal (Bastida and Talavera 2002; Bastida et al. 2009). Fire significantly promoted the germination of Cistus as a group, but only in one species (C. albidus) reached the level of statistical significance, which emphasizes the importance of heat as a germination trigger in this genus. Nevertheless, the number of seedlings germinating without fire was still quite high, which corroborates that these species can benefit from fire but are not strict fire-dependent.

LS soils produced more herb seedlings than ES soils, mainly due to the dicots. Furthermore, on 
average, burned soils produced fewer seedlings than unburned soils, particularly for monocots. These results highlight the relevance of the fire season for functional group composition. Even though fire had a negative effect on herbs in both seasons, early season fires will produce fewer seedlings and will result in a community with similar proportion of monocots and dicots. By contrary, fires later in the season will produce more seedlings and these will be dominated by dicots.

We suggest that, provided moisture and appropriate temperature, germination proceeds rapidly in this shrubland. Thus, the extended period of germination observed in field studies (Quintana et al. 2004; Daskalakou and Thanos 2004; De Luis et al. 2008) is probably mostly due to lack of moisture. It is arguable that germination of this soil seed bank is primarily controlled by the availability of water (i.e., rainfall in the field). This implies that changes in rainfall patterns can affect overall germination. Because germination is highly sensitive to soil moisture (Thomas et al. 2010), one can argue that less frequent pulses of high precipitation might be less effective in triggering germination than more frequent pulses of less intense rainfall. Based on a range of emission scenarios, climate models project a decrease in precipitation for the Mediterranean region, rainfall being anticipated to occur as more intense, but less frequent events (Giorgi and Lionello 2008), which coincides with recent observations (Esteban-Parra et al. 1998). High-intensity less frequent rainfall can increase the growth of established plants (Heisler-White et al. 2008). It is therefore tenable that post-fire regeneration from seeds may be negatively affected by such a rainfall pattern, whereas regeneration by vegetative growth (i.e., resprouting) might be positively affected (Ojeda et al. 2005). Nevertheless, since in the current study most seeds germinated under simulated-autumn, it remains to be seen how germination would be affected if rainfall patterns were shifted toward colder, winter conditions. Further studies are needed to more clearly define the effects of precipitation changes due to climate change on the two mechanisms of regeneration.

In summary, this study shows that changes in the fire season can alter the relative proportion of shrub and herbs in the seedling community. ES fires produced a slightly more diverse community of shrub seedlings and a more balance abundance of the two main functional groups of herbs (monocots, dicots). In contrast, LS fires produced more herbaceous dicots, and favored Cistus dominance. The greater abundance of dicots and the low abundance of $R$. officinalis in LS fires suggest that a combination of ES and LS fires might be more beneficial for maintaining higher species diversity in this shrubland.

Acknowledgments The authors thank the EC (EVG1CT2001-00027) for funding, and F. Rodríguez y Silva (Cordoba University), Julio Ruiz Ortiz and Eduardo Nicolás Dueñas (Centro Operativo Provincial de Córdoba, Infoca, Junta de Andalucía) and the crews from EGMASA for their support during the experimental burns.

\section{References}

Arianoutsou-Faraggitaki M (1984) Post-fire successional recovery of a phryganic (east Mediterranean) ecosystem. Acta Oecol 5(19):387-394

Auld TD, Bradstock RA (1996) Soil temperatures after the passage of a fire: do they influence the germination of buried seeds? Aust J Ecol 21:106-109

Baskin C, Baskin J (1998) Seeds, ecology, biogeography, and evolution of dormancy and germination. Academic Press, San Diego

Bastida F, Talavera S (2002) Temporal and spatial patterns of seed dispersal in two Cistus species (Cistaceae). Ann Bot 89:427-434

Bastida F, Talavera S, Ortiz PL, Arista M (2009) The interaction between Cistaceae and a highly specific seed-harvester ant in a Mediterranean scrubland. Plant Biol 11:46-56

Buisson E, Dutoit T, Torre F, Romermann C, Poschlod P (2006) The implications of seed rain and seed bank patterns for plant succession at the edges of abandoned fields in Mediterranean landscapes. Agric Ecosyst Environ 115:6-14

Clemente AS, Rego FC, Correia OA (1996) Demographic patterns and productivity of post-fire regeneration in Portuguese Mediterranean Maquis. Int J Wildland Fire 6:5-12

Clemente A, Rego F, Correia O (2007) Seed bank dynamics of two obligate seeders, Cistus monspeliensis and Rosmarinus officinalis, in relation to time since fire. Plant Ecol 190:175-188

Daskalakou EN, Thanos CA (2004) Postfire regeneration of Aleppo pine-the temporal pattern of seedling recruitment. Plant Ecol 171:81-89

De Luis M, Verdú M, Raventós J (2008) Early to rise makes a plant healthy, wealthy, and wise. Ecology 89:3061-3071

Enright NJ, Lamont BB (1989) Seed banks, fire season, safe sites and seedling recruitment in 5 co-occurring Banksia species. J Ecol 77:1111-1122

Espigares T, Peco B (1993) Mediterranean pasture dynamicsthe role of germination. J Veg Sci 4:189-194

Esteban-Parra MJ, Rodrigo FS, Castro-Díez Y (1998) Spatial and temporal patterns of precipitation in Spain for the period 1880-1992. Int J Climatol 18:1557-1574

FAO (1974) Food and agriculture organization. Soil Map of the World: Vol. I, Legend. UNESCO, Paris 
Fenner M, Thompson K (2005) The ecology of seeds. Cambridge University Press, Cambridge

Figueroa JA, Teillier S, Jaksic FM (2004) Composition, size and dynamics of the seed bank in a Mediterranean shrubland of chile. Aust Ecol 29:574-584

Giménez-Benavides L, Escudero A, Pérez-García F (2005) Seed germination of high mountain Mediterranean species: altitudinal, interpopulation and interannual variability. Ecol Res 20:433-444

Giorgi F, Lionello P (2008) Climate change projections for the Mediterranean region. Global Planet Change 63:90-104

Heisler-White JL, Knapp AK, Kelly EF (2008) Increasing precipitation event size increases aboveground net primary productivity in a semi-arid grassland. Oecologia 158: 129-140

Keeley JE, Fotheringham CJ, Baer-Keeley M (2006) Demographic patterns of postfire regeneration in Mediterraneanclimate shrublands of California. Ecol Monographs 76:235-255

Knox KJE, Clarke PJ (2006) Fire season and intensity affect shrub recruitment in temperate sclerophyllous woodlands. Oecologia 149:730-739

Luna B, Pérez B, Céspedes B, Moreno JM (2008) Effect of cold exposure on seed germination of 58 plant species comprising several functional groups from a mid-mountain Mediterranean area. Ecoscience 15:478-484

Moreira B, Tormo J, Estrelles E, Pausas JG (2010) Disentangling the role of heat and smoke as germination cues in Mediterranean Basin flora. Ann Bot 105:627-635

Moreno JM, Oechel WC (1992) Factors controlling postfire seedling establishment in southern California chaparral. Oecología 90:50-60

Moreno JM, Cruz A (2000) La respuesta de las plantas al fuego: factores y mecanismos. In: Vélez R (ed) La lucha contra los incendios forestales: fundamentos experiencias $\mathrm{y}$ aplicaciones. Mc Graw-Hill, Madrid, pp 413-436

Ojeda F, Brun FG, Vergara JJ (2005) Fire, rain and the selection of seeder and resprouter life-histories in fire-recruiting, woody plants. New Phytol 168:155-165

Ooi MKJ (2010) Delayed emergence and post-fire recruitment success: Effects of seasonal germination, fire season and dormancy type. Aust J Bot 58:248-256

Ortega M, Levassor C, Peco B (1997) Seasonal dynamics of Mediterranean pasture seed banks along environmental gradients. J Biogeogr 24:177-195

Pérez B, Moreno JM (1998) Fire-type and forestry management effects on the early postfire vegetation dynamics of a Pinus pinaster woodland. Plant Ecol 134:27-41

Quintana JR, Cruz A, Fernández-González F, Moreno JM (2004) Time of germination and establishment success after fire of three obligate seeders in a Mediterranean shrubland of central Spain. J Biogeogr 31:241-249

Reyes O, Trabaud L (2009) Germination behaviour of 14 Mediterranean species in relation to fire factors: smoke and heat. Plant Ecol 202:113-121

Roy J, Sonie L (1992) Germination and population-dynamics of Cistus species in relation to fire. J Appl Ecol 29:647-655

Salvador R, Lloret FL (1995) Germinación en el laboratorio de varias especies arbustivas mediterráneas: efecto de la temperatura. Orsis 10:25-34

Seifan M, Tielborger K, Kadmon R (2010) Direct and indirect interactions among plants explain counterintuitive positive drought effects on an eastern Mediterranean shrub species. Oikos 119:1601-1609

Thomas PB, Morris EC, Auld TD, Haigh AM (2010) The interaction of temperature, water availability and fire cues regulates seed germination in a fire-prone landscape. Oecologia 162:293-302

Torres I, Urbieta RI, Moreno JM (2012) Vegetation and soil seed bank relationships across microhabitats in an abandoned Quercus suber parkland under simulated fire. Ecoscience 19 , I (in press)

Traba J, Azcárate FM, Peco B (2006) The fate of seeds in Mediterranean soil seed banks in relation to their traits. J Veg Sci 17:5-10

Trabaud L (1994) Diversity of the soil seed bank of a Mediterranean Quercus ilex forest. Biol Conserv 69:107-114

Trabaud L, Casal M (1989) Response of Rosmarinus officinalis seeds on different simulations of fire. Acta Oecol 10:355-363

Trabaud L, Oustric J (1989) Comparison between the post-fire regeneration strategies of 2 Cistus Species. Revue d'Écologie-La Terre et la Vie 44:3-13

Trigueros Vera D, Parra Martín P, Rossini Oliva S (2010) Effect of chemical and physical treatments on seed germination of Erica australis. Annales Botanici Fennici 47:353-360

Troumbis A, Trabaud L (1987) Seed bank dynamics of 2 Cistus species in Greek Mediterranean-type ecosystems. Acta Oecol 8:167-179

Tutin TG, Heywood VH, Burges NA, Moore DM, Valentine DH, Walters SM, Webbs DAE (1964-1980) Flora Europaea. Cambridge University Press, Cambridge

Valbuena L, Trabaud L (2001) Contribution of the soil seed bank to post-fire recovery of a heathland. Plant Ecol 152:175-183

Vázquez A, Moreno JM (1998) Patterns of lightning-, and people-caused fires in peninsular Spain. Int J Wildland Fire 8(2):103-115

Verdú M, Traveset A (2005) Early emergence enhances plant fitness: a phylogenetically controlled meta-analysis. Ecology 86:1385-1394 